Pendas : Jurnal IImiah Pendidikan Dasar, ISSN Cetak : 2477-2143 ISSN Online : 2548-6950 Volume II Nomor 2, Desember 2017

\title{
AKTIVITAS GURU DAN SISWA DALAM PEMBELAJARAN MATEMATIKA MENGGUNAKAN CONTEXTUAL TEACHING AND LEARNING (CTL) DI SEKOLAH DASAR
}

\author{
Rina Indriani \\ PGSD FKIP Universitas Pasundan \\ rinaindriani@unpas.ac.id
}

\begin{abstract}
School teaching activities are part of educational activities to guide students toward better conditions. One of those taught in school is a field of mathematics study. In general, students think that math lesson is one of the hardest and frightening lessons. To be able to change the views of students on mathematics subjects, it must be made learning that can make students interested and motivated to learn math. Thus, mathematical learning is no longer considered to be frightening learning. One way to support it, it must be chosen strategy / learning model in accordance with the condition of students. One of them is by using Contextual Teaching and Learning (CTL). Research subjects in this study are students of grade V SDN Singawada I District Rajagaluh Majalengka District. The instrument used in this research is the observation sheet of teacher and student activity. Based on the above data analysis, it can be concluded that: Cotextual Teaching and Learning (CTL) applied in this research can be implemented well by teachers and students respond positively every activity in learning.
\end{abstract}

Keywords: Contextual Teaching and Learning, Teacher Activity, Student Activity

\begin{abstract}
ABSTRAK
Kegiatan pengajaran disekolah adalah bagian dari kegiatan pendidikan untuk membimbing siswa menuju keadaan yang lebih baik. Salah satu yang diajarkan disekolah adalah bidang studi matematika. Pada umumnya siswa berpendapat bahwa pelajaran matematika merupakan salah satu pelajaran yang sukar dan menakutkan. Untuk dapat mengubah pandangan siswa terhadap mata pelajaran matematika, maka harus dibuat pembelajaran yang dapat membuat siswa tertarik dan termotivasi untuk belajar matematika. Sehingga, pembelajaran matematika tidak lagi dipandang menjadi pembelajaran menakutkan. Salah satu cara untuk mendukung hal tersebut, maka harus dipilih strategi/model pembelajaran yang sesuai dengan kondisi siswa. Salah satunya adalah dengan menggunakan Contextual Teaching and Learning (CTL). Subjek penelitian dalam penelitian ini adalah siswa kelas V SDN Singawada I Kecamatan Rajagaluh Kabupaten Majalengka. Instrumen yang digunakan dalam penelitian ini adalah lembar observasi aktivitas guru dan siswa. Berdasarkan analisis data diatas, maka dapat disimpulkan bahwa: Cotextual Teaching and Learning (CTL) yang diterapkan
\end{abstract}


Pendas : Jurnal Ilmiah Pendidikan Dasar, ISSN Cetak : 2477-2143 ISSN Online : 2548-6950 Volume II Nomor 2, Desember 2017

dalam penelitian ini dapat dilaksanakan dengan baik oleh guru dan siswa merespon secara positif setiap aktivitas dalam pembelajaran.

Kata Kunci : Contextual Teaching and Learning, Aktivitas Guru, Aktivitas Siswa

\section{A. Pendahuluan}

Kegiatan

pengajaran

disekolah adalah bagian dari kegiatan pendidikan untuk membimbing siswa menuju keadaan yang lebih baik. Salah satu yang diajarkan disekolah adalah bidang studi matematika. Pada umumnya siswa berpendapat bahwa pelajaran matematika merupakan salah satu pelajaran yang sukar dan menakutkan.

Untuk dapat mengubah pandangan siswa terhadap mata pelajaran matematika, maka harus dibuat pembelajaran yang dapat membuat siswa tertarik dan termotivasi untuk belajar matematika. Sehingga, pembelajaran matematika tidak lagi dipandang menjadi pembelajaran menakutkan.

Salah satu cara untuk mendukung hal tersebut, maka harus dipilih strategi/model pembelajaran yang sesuai dengan kondisi siswa. Salah satunya adalah dengan menggunakan Contextual Teaching and Learning (CTL).

The Northwest Regional Education aboratory USA (Manshur, 2011: 20) mengidentifikasi adanya 6 kunci dasar yang menentukan kualitas dari Contextual Teaching and Learning (CTL), yakni:

1) Pembelajaran bermakna

2) Penerapan pengetahuan

3) Berpikir tingkat tinggi

4) Kurikulum yang dikembangkan berdasarkan kepada standar

5) Responsi terhadap budaya

6) Penilaian autentik

Berbagai macam strategi penilaian digunakan untuk mengetahui kemampuan siswa yang sesungguhnya meliputi: penilaian proyek dan kegiatan siswa, serta panduan pengamatan langsung disamping memberikan kesempatan kepada siswa untuk aktif menilai pembelajaran mereka sendiri. Hal tersebut dapat melatih 
Pendas : Jurnal IImiah Pendidikan Dasar, ISSN Cetak : 2477-2143 ISSN Online : 2548-6950 Volume II Nomor 2, Desember 2017

siswa untuk mengembangkan kemampuan yang dimilikinya.

Selain itu, dengan Contextual Teaching and Learning (CTL) siswa lebih memahami materi dan pembelajarn yang diajarkan, karena dikaitkan dengan keadaan hidup mereka. Hal ini dapat menjadi bekal siswa dalam mengembangkan pemahaman mereka terhadap suatu konsep tertentu.

\section{Berdasarkan}

latar

belakang di atas, maka rumusan masalah dalam penelitian ini adalah sebagai berikut:

Bagaimanakah gambaran aktivitas guru dan siswa dalam Contextual Teaching and Learning?

$$
\text { Adapun tujuan dari }
$$

penelitian ini adalah untuk Mendeskripsikan aktivitas guru dan siswa dalam pembelajaran matematika dengan menggunakan CTL

\section{B. Landasan Teori}

Pembelajaran merupakan proses komunikasi dua arah, mengajar dilakukan oleh guru sebagai pendidik, sedangkan belajar dilakukan oleh peserta didik atau siswa. Sehingga, aktivitas guru dan siswa dalam pembelajaran sangat penting dalam kesuksesan proses belajar mengajar. Selain itu, respon siswa terhadap pembelajaran bisa menjadi landasan bagi guru dalam merencanakan pembelajaran selanjutnya.

Contextual Teaching and Learning (CTL) lahir berawal dari "Adanya dualisme antara abstrak dan nyata, pikiran dan tindakan, konsep dan praktik. Dualisme ini memisahkan sisi-sisi abstrak dan sisi-sisi nyata. Sisi abstrak yaitu gagasan-gagasan, konsep, pengetahuan itu sendiri dan kumpulan informasi. Sisi nyata yaitu tindakan praktis didalam dunia keseharian, situasi aktual dan masalah-masalah nyata" Johnson (2008: 34 ).

\section{Menurut Sanjaya (2006:} 255), "Pendekatan kontekstual adalah suatu strategi pembelajaran yang menekankan kepada proses keterlibatan siswa secara penuh untuk dapat menemukan materi yang dipelajari dan menghubungkannya dengan strategi nyata sehingga 
Pendas : Jurnal Ilmiah Pendidikan Dasar, ISSN Cetak : 2477-2143 ISSN Online : 2548-6950 Volume II Nomor 2, Desember 2017

mendorong siswa untuk dapat menempatkannya dalam kehidupan mereka sehari-hari".

Menurut Johnson (2008: 65) "CTL adalah sebuah sistem yang menyeluruh. CTL terdiri dari bagian- bagian yang saling terhubung. Jika bagian-bagian ini terjalin satu sama lain, maka akan dihasilkan pengaruh yang melebihi hasil yang diberikan bagianbagiannya secara terpisah. Setiap bagian CTL yang berbeda-beda ini memberikan sumbangan dalam menolong siswa memahami tugas sekolah. Secara bersama-sama mereka mereka membentuk suatu sistem yang memungkinkan para siswa melihat makna di dalamnya, dan mengingat materi”.

Beberapa ciri khas dalam Contextual Teaching and Learning (CTL) (Manshur, 2011:16) antara lain sebagai berikut:

1. Titik awal proses pembelajarannya adalah penggunaan masalah berkonsteks nyata (kontekstual) yang konkrit atau yang ada dalam alam pikiran siswa.

2. Pembelajaran ini menghindari cara mekanik yaitu berfokus pada prosedur penyelesaian soal.

3. Siswa diperlakukan sebagai peserta aktif dengan diberi keleluasaan menemukan sendiri atau mengembangkan alat, model, dan pemahaman matematis melalui penemuan dengan bantuan guru atau diskusi bersama teman.

Ditjen Dikdasmen (2003: 10-19) menyebutkan tujuh komponen utama Contextual Teaching and Learning (CTL), yaitu:

1) Konstruktivisme (Contructivism).

2) Menemukan (Inquiry)

3) Bertanya (Questioning)

4) Masyarakat Belajar (Learning Community)

5) Pemodelan (Modelling)

6) Refleksi (Reflection)

7) Penilaian yang Sebenarnya (Authentic Assessment)

Dari uraian diatas, dapat disimpulkan bahwa Contextual Teaching and Learning (CTL) adalah pembelajaran yang menggunakan pemikiran tingkat tinggi yang mengaitkan antara konsep abstrak (pegetahuan) dengan konteks nyata dalam 
Pendas : Jurnal IImiah Pendidikan Dasar, ISSN Cetak : 2477-2143 ISSN Online : 2548-6950 Volume II Nomor 2, Desember 2017

kehidupan sehari-hari dimana dalam penilaiannya berupa penilaian autentik yang tidak hanya sekedar dilihat dari hasil belajar semata.

\section{Metode Penelitian}

Menurut Sugiyono (2010, hlm. 3) secara umum metode penelitian diartikan sebagai cara ilmiah untuk mendapatkan data dengan tujuan dan kegunaan tertentu.

Metode yang digunakan dalam penelitian ini adalah kualitatif dengan teknik observasi. Observasi merupakan pengamatan terhadap suatu objek yang diteliti baik secara langsung maupun tidak langsung (Satori, 2011,105).

Observasi dalam penelitian ini untuk mengobservasi aktivitas guru dan siswa dalam pelaksanaan Contextual Teaching and Learning.

\section{Hasil Penelitian dan}

\section{Pembahasan}

\section{Aktivitas Guru}

Aspek yang dinilai untuk kinerja guru merupakan kegiatankegiatan yang dilakukan selama pembelajaran yaitu kegiatan awal, kegiatan inti, dan kegiatan akhir. Setiap aspek yang ada dalam kegiatan pembelajaran sudah tercantum pada observasi kinerja guru. Aspek tersebut meliputi 7 komponen utama CTL, yaitu: konstruktivisme, menemukan, bertanya, masyarakat belajar, pemodelan, refleksi, dan penilaian yang sebenarnya.

Dari hasil penelitian, didapat data hasil aktivitas guru dalam Contextual Teaching Learning. Data tersebut dapat dilihat dalam Tabel 1.

Tabel 1

Data Hasil Aktivitas Guru

\begin{tabular}{|c|c|c|}
\hline $\begin{array}{c}\text { Pertemua } \\
\mathbf{n}\end{array}$ & $\begin{array}{c}\text { Presentas } \\
\mathbf{e}\end{array}$ & $\begin{array}{c}\text { Kategor } \\
\mathbf{i}\end{array}$ \\
\hline 1 & $76 \%$ & Baik \\
\hline 2 & $82 \%$ & Baik \\
\hline 3 & $89 \%$ & Baik \\
\hline 4 & $94 \%$ & Baik \\
\hline Jumlah & $341 \%$ & \multirow{2}{*}{ Baik } \\
\hline Rerata & $85,25 \%$ & \\
\cline { 1 - 2 }
\end{tabular}

Dari Tabel 1 diperoleh aktivitas guru dengan rata-rata $85,25 \%$. Hal ini menunjukkan bahwa tingkat aktivitas guru memiliki kategori baik dalam 
Pendas : Jurnal IImiah Pendidikan Dasar, ISSN Cetak : 2477-2143 ISSN Online : 2548-6950 Volume II Nomor 2, Desember 2017

Contextual Teaching and Learning (CTL).

\section{Aktivitas Siswa}

Aspek yang dinilai untuk aktivitas siswa merupakan kegiatan-kegiatan siswa selama pembelajaran. Aspek yang dinilai sudah tercantum dalam pedoman observasi aktivitas siswa. Aspek tersebut meliputi 7 komponen utama CTL, yaitu: konstruktivisme, menemukan,

bertanya, masyarakat belajar, pemodelan, refleksi, dan penilaian yang sebenarnya. Dimana penekanan aktivitas siswa yaitu pada aspek kerjasama, keaktifan, cara kerja, dan kemampuan matematis siswa.

Dari hasil penelitian, didapat data hasil aktivitas siswa dalam Contextual Teaching Learning. Data tersebut dapat dilihat dalam Tabel 2.

Tabel 2

Data Hasil Aktivitas Siswa

\begin{tabular}{|c|c|c|}
\hline $\begin{array}{c}\text { Pertemua } \\
\mathbf{n}\end{array}$ & $\begin{array}{c}\text { Presentas } \\
\mathbf{i}\end{array}$ & $\begin{array}{c}\text { Kategor } \\
\mathbf{i}\end{array}$ \\
\hline 1 & $55 \%$ & Baik \\
\hline 2 & $66 \%$ & Baik \\
\hline 3 & $76 \%$ & Baik \\
\hline 4 & $89 \%$ & Baik \\
\hline Jumlah & $286 \%$ & \multirow{2}{*}{ Baik } \\
\hline Rerata & $71,50 \%$ & \multirow{2}{*}{} \\
\cline { 1 - 2 } & \multicolumn{1}{|c|}{}
\end{tabular}

Dari Tabel 2 diperoleh aktivitas guru dengan rata-rata $71,50 \%$. Hal ini menunjukkan bahwa tingkat aktivitas siswa memiliki kategori baik dalam Contextual Teaching and Learning (CTL)

Aktivitas guru dan siswa pada Contextual Teaching and Learning dilakukan oleh peneliti dan guru kelas V. Proses pengamatan dilakukan sedemikian rupa sehingga tidak mengganggu proses pembelajaran yang sedang berlangsung.

Secara umum, pembelajaran pada kelas yang memperoleh Contextual Teaching and Learning mengalami peningkatan. Jika pada pertemuan pertama siswa kurang kondusif dalam pembelajaran, misalnya siswa masih malu-malu dalam bertanya, maka pada pertemuan kedua dan selanjutnya siswa sudah mulai terbiasa dengan pembelajaran yang dilakukan.

Selain itu, pelaksanaan Contextual Teaching and Learning dapat lebih mengaktifkan siswa, melatih siswa untuk dapat saling bertukar pikiran dengan teman 
Pendas : Jurnal IImiah Pendidikan Dasar, ISSN Cetak : 2477-2143 ISSN Online : 2548-6950 Volume II Nomor 2, Desember 2017

sekelompoknya, saling membantu dalam menyelesaikan tugas yang diberikan guru, dan memberikan keleluasaan berpikir pada siswa. Dengan adanya diskusi maka siswa akan lebih mudah memahami konsep, melatih rasa saling menghargai pendapat teman serta dapat meningkatkan motivasi belajar siswa.

Walaupun demikian, tidak semua siswa dapat berpartisifasi aktif dalam pembelajaran. Berdasarkan temuan peneliti dalam penelitian ini, ada beberapa siswa yang kurang menyukai pembelajaran ini, dengan berbagai alasan, diantaranya siswa belum mengerti materi yang dibahas. Selain itu, pada saat proses pembelajaran terjadi kegaduhan, karena siswa belum mengerti tahap-tahap pembelajaran yang dilakukan. Namun hal ini hanya terjadi pada pertemuan pertama, untuk pertemuan selanjutnya siswa sudah mengerti apa yang harus dilakukan dalam proses pembelajaran.

Pada prinsipnya Contextual Teaching and Learning memberi banyak kelebihan diantaranya siswa dapat memahami bahwa matematika bukanlah mata pelajaran yang abstrak dan sulit dimengerti, tetapi matematika juga bisa memberikan pengalaman belajar yang mungkin akan bermanfaat bagi kehidupan. Hal ini sejalan dengan pendapat Nurhadi (2002: 1) bahwa Contextual Teaching and Learning (CTL) adalah pendekatan dengan konsep belajar yang membantu guru mengaitkan antara materi yang diajarkan dengan situasi dunia nyata dan mendorong siswa membuat hubungan antara pengetahuan yang dimiliki dan penerapannya dalam kehidupan.

\section{E. Kesimpulan}

Berdasarkan analisis data diatas, maka dapat disimpulkan bahwa: Cotextual Teaching and Learning (CTL) yang diterapkan dalam penelitian ini dapat dilaksanakan dengan baik oleh guru dan siswa merespon secara positif setiap aktivitas dalam pembelajaran.

Pada setiap proses belajar mengajar yang dilakukan, harus diupayakan agar dapat 
Pendas : Jurnal Ilmiah Pendidikan Dasar,

meningkatkan hasil belajar siswa.

Hal ini dapat terwujud apabila semua fasilitas pembelajaran terutama menyangkut model dan bentuk tugas yang diterapkan dalam pembelajaran matematika dapat dirancang sedemikian rupa sehingga mencerminkan keterlibatan siswa dalam mengembangkan kemampuannya.

\section{DAFTAR PUSTAKA}

Ditjen Dikdasmen Depdiknas RI. (2003). Pendekatan Kontekstual (Contextual Teaching and Learning). Jakarta: Ditjen Dikdasmen Depdiknas.

Johnson, E. B. (2008). Contextual Teaching and Learning: Menjadikan Kegiatan Belajar dan Mengajar Mengasyikan dan Bermakna. Pengantar: Prof. Dr. A. Chaedar Alwasilah.
Bandung: Mizan Learning Center.

Manshur. (2011). Implementasi Pembelajaran Matematika Kontekstual untuk Meningkatkan Kemampuan Pemahaman dan Sikap Siswa terhadap Matematika Siswa Sekolah Dasar.Tesis. UPI Bandung: Tidak Dipublikasikan.

Nurhadi. (2004). Kurikulum 2004 Pertanyaan dan Jawaban. Jakarta: Grasindo

Sanjaya, W. (2006). Strategi Pembelajaran. Jakarta: Kencana Prenada Media Group.

Satori, Dja'an \& Aan Komariah. (2011). Metodologi Penelitian Kualitatif. Bandung: Alfabeta

Sugiyono. (2010). Metode Penelitian Pendidikan. Bandung: Alfabeta. 